\title{
Postoperative contamination of mandibular osteotomy sites with saliva
}

\author{
R. KOOLE AND P. EGYEDI
}

Department of Oral Surgery, State University of Utrecht, The Netherlands and Department of Oral Surgery, Faculty of Dentistry, National University of Singapore, Singapore

\begin{abstract}
Postoperative salivary contamination of surgical wounds around the mandible was found in several types of osteotomy and bone grafting procedure. This problem was investigated by determining the amylase content of wound secretions in redon bottles every $24 \mathrm{~h}$. The implications for antibiotic prophylaxis are discussed.
\end{abstract}

(Accepted for publication 30 November 1986)

Continuous suction is practiced frequently after osteotomies and other oral surgical procedures in order to eliminate accumulation of secretions. It may have the disadvantage that saliva is drawn into the field of surgery as long as the seal towards the oral cavity is not "water-tight". In this paper, we report on an investigation into this problem. The amylase content of the secretions obtained from surgical wounds, primarily open towards the oral cavity, was determined in several types of osteotomy and bone graft procedure. The results of osteotomies and ridge augmentation of the visor-sandwich type will be reported in this paper.

It was assumed that the amylase content of the secretions in the suction redon bottles was an indication of saliva leakage into the field of surgery, if elevated values (as compared to the plasma level) were obtained.

\section{Material and methods}

The several types of osteotomy and bone graft procedure in 34 patients are depicted in Fig. 1.

Drains of the redon-type were inserted and bottles were examined daily until the drains could be removed, as secretion was reduced to an insignificant level. Because of the continuous suction drainage, extra efforts to prevent leakage were taken, including strapping of the lower lip (Fig. 2 ), gastric tube feeding in some cases, and careful handling of the surgical site during cleaning of the mouth.

Measurements of the amylase content were performed with the Phadebas method*. Normal serum amylase values are between 100-350 Uh, independent of factors such as food intake, diet, muscle activity and haemolysis ${ }^{13}$. It was assumed that an amylase content between $350 \mathrm{U} / 1000$ U/ after the 2 nd day was probably due to minor salivary leakage into the wound. A content between $1000-5000$ was likely to be caused by a

\footnotetext{
*Pharmacia Diagnostics AB, Uppsala,
} Sweden. 
number

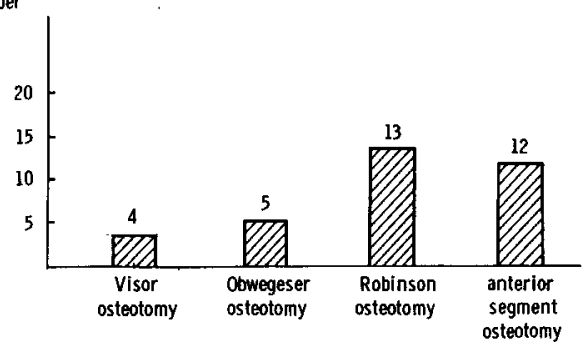

Fig. 1. Patient material.

considerable leakage and amounts larger than 5000 , point to a major dehiscence of the wound, viz, 2 upper dots in Fig. 3 at days 2 and 3.

\section{Results}

The first 3 days values are depicted in Fig. 3. The drawn and interrupted lines represent averages. The separate marks (29 esti-

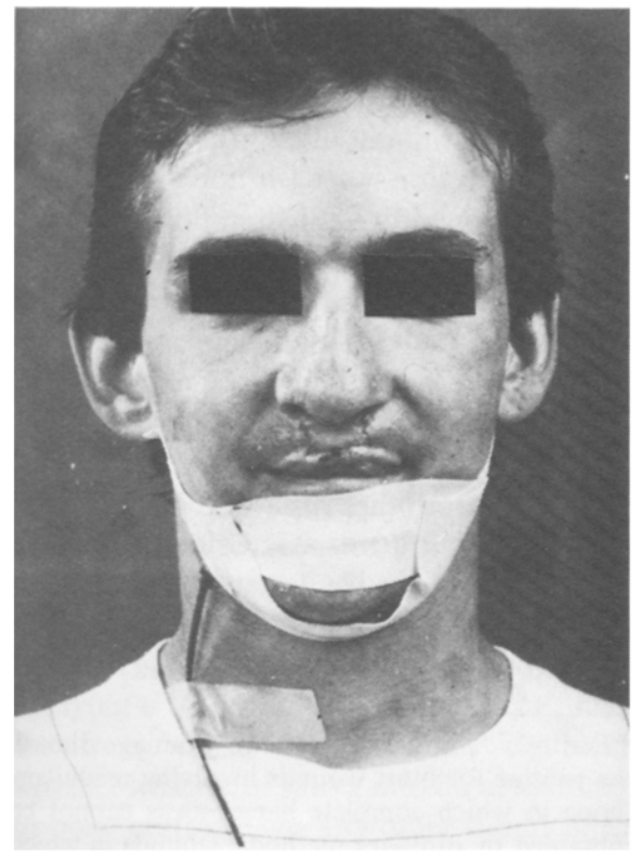

Fig. 2. Strapping and drain in a patient with an anterior segmental osteotomy.

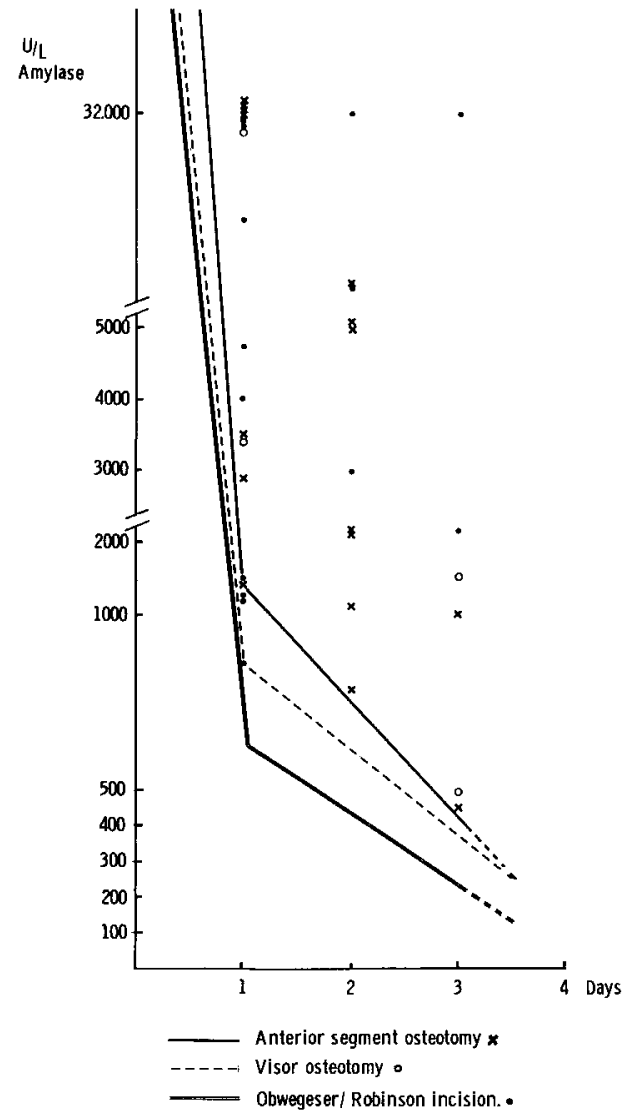

Fig. 3. Amylase content of secretions; for explanation see text.

mations out of a total of 106) represent the above average values. After post-operative day 3 , the secretions as a rule diminished such that the drains were removed. Elevated contents were found in 2 out of 4 visor osteotomy cases, in 5 out of 18 oblique subcondylar osteotomyObwegeser-Dal Pont cases and in 8 out of 12 anterior segmental osteotomy cases.

As can be seen, it is especially in the anterior segment type of osteotomy that an elevation of the amylase content was found after the first postoperative day.

From Fig. 3, it also becomes clear that even the higher levels of amylase content 
Table 1. Some published results from the Utrecht clinic for Maxillo-facial Surgery

\begin{tabular}{lcc}
\hline Type of surgery & No. of patients & $\%$ infection \\
\hline oblique subcondylar osteotomy $^{6}$ & 100 & 6 \\
segmental anterior (Hofer) $^{11}$ & 18 & 0 \\
segmental anterior (Köle) $^{12}$ & 44 & 0 \\
major mandibular reconstructions $^{7}$ (free bone grafts) & 38 & $26.3^{*}$ \\
\hline
\end{tabular}

*Total graft loss in 3 patients $(7.9 \%)$.

tend to decrease, but they may reach serum levels only after a period beyond 3 days, if suction were continued.

\section{Discussion}

Our findings may have some implications with regard to the duration of antibiotic prophylaxis. They may indicate that contamination of the surgical field with saliva occurs at least up to the $3 \mathrm{rd}$ postoperative day. It is assumed that the amylase content of the first sample is caused by saliva introduced into the wound during surgery. Significance can therefore only be attached to the amylase content of the secretions after the first day, provided the parotid or other gland(s) have not been damaged secreting saliva into the field of surgery. Especially where a bone graft is at risk of being lost, one should therefore consider antibiotic prophylaxis well beyond this time. Whether one could manage patients by taking daily samples of fluid collected in the redon-system and having them examined on their amylase content seems still debatable to us. A more rational approach seems to be to "defend" the osteotomy site routinely against infection for at least a week. This statement is not in accordance with modern trends in general surgery where short-term prophylaxis seems to prevail nowadays ${ }^{3,17}$.

The wound infection rates in maxillo-facial surgery, being much higher than in other surgical specialties (see below), seem, however, to warrant such a basically different approach.
It is, however, clear that in view of our findings, the use of suction drainage should be questioned. Is it necessary useful to drain osteotomy sites? The object of course is to eliminate dead space and obtain a rapid adaptation of the covering soft tissues to the underlying bone, especially in cases where bone grafts have been used. Since up to 200 $\mathrm{ml}$ of secretions can be found occasionally in a vacuum bottle after $24 \mathrm{~h}$ (even in anterior segmental osteotomies), the argument in favour of continuous suction drainage seems to have a certain logic. It seems unlikely that such large amounts of secretionsblood can be resorbed in a few days. However, we have never conducted a comparative study on 2 groups (one with, one without continuous suction) with regard to wound infection.

We can therefore only point to the general surgical principle as outlined above in favour of our practice and also to common practice in orthopaedic bone surgery*, especially where free bone grafts are inserted. Finally, as already indicated above we can also point to the high infection rate of mandibular osteotomies (up to $21.7 \%$ ) reported by some ${ }^{1,2,20}$, not to speak of the high infection rate in mandibular reconstruction as reported by others ${ }^{7,16,19}$. Our own results for wound infections are presented in Table 1.

\footnotetext{
*Smith": "The use of suction drainage should be routine for most wounds involving medullary bone in which complete haemostasis cannot be obtained by ordinary methods, wounds in which there is a dead space, and after most major operations on the hip or spine".
} 
As to the question of whether leakage of saliva can be equated with the increased likelihood of infection, the following considerations seem relevant. Saliva is sterile as it is secreted, but in the oral cavity, the bacterial count in $1 \mathrm{ml}$ of whole saliva is $10^{7}$ aerobic micro-organisms plus $5 \cdot 10^{8}$ anaerobic ones ${ }^{10}$. Many species found in saliva are also found in infections after head and neck surgery ${ }^{14}$. Clearly, saliva entering a wound through a dehiscence in the suture line may be assumed to contaminate the osteotomybone graft site producing infection if the local and general circumstances for its development are favourable.

Are there other ways in which saliva could be operative inside a wound? In addition to bacteria, saliva contains several constituents which might in theory be of importance in oral infections. We will discuss 2 of them. Lysozyme in combination with complement has bactericidal activity. However, it is inactive against the normal oral flora ${ }^{21}$. It could theoretically be active against contaminant germs, which circulates in hospitals, and as such be of some value in preventing infection with, say, one or another gram-negative rods. This, however, is purely speculative. Fibrinolysins and their inhibitors are found in saliva. Fibrinolysis can destruct a blood clot, and also the clot in or around an osteotomy site. These substances are thought to play a rôle in post-extraction alveolitis ${ }^{5,15}$ but local plasminogen activators seem to be more important than salivary fibrinolytic agents ${ }^{4}$, and fibrinolytic inhibitors in normal whole saliva seem to have no physiological importance at all ${ }^{8}$. Moreover, it has not been possible to reduce the incidence of alveolitis by applying a local fibrinolytic inhibitor ${ }^{9}$, and therefore, all in all, it seems doubtful whether leakage of saliva into an osteotomy or bone graft site has any other significance than of being a vehiculum for oral bacteria. The final answer to the problems in- volved seems to be the conduction of a comparative clinical study. For ethical reasons, such a study can hardly be set up by such "believers" as the authors of this paper.

\section{References}

1. Balan, E. H.: Entzündliche Komplikationen bei der chirurgischen Dysgnathiebehandlung nach sagittaler, retromolarer Osteotomie im aufsteigenden Unterkieferast. In: PFEIFER G. \& SCHWENZER, N. (eds.): Fortschr. KieferGesichtschirurgie 1984: 29: 63-65. Stuttgart: Thieme.

2. Beckers H., Kühnle T. \& Dietrich H. G.: Einfluss prophylaktischer Antibiose auf infektiöse Komplikationen nach Dysgnathieoperation. In: Preifer, G., Schwenzer, N. (eds.): Fortschr. Kiefer-Gesichtschirurgie 1984: 29: 118-119. Stuttgart: Thieme.

3. Bergman, B. R.: Antibiotic prophylaxis in open and closed factures. Acta Orthop. Scand. 1982: 53: 57-62.

4. BIRN, H.: Fibrinolytic activity in "dry socket". Acta Odontol. Scand. 1970: 28: 37 . 58.

5. BIRN, H.: Etiology and pathogenesis of fibrinolytic alveolitis ("dry socket"). Int. J. Oral Surg. 1973: 2: 211-267.

6. Egyedi, P., Houwing, M \& Juten E.: The oblique subcondylar osteotomy: report of results of 100 cases. J. Oral Surg. 1981: 39: 111-113.

7. EGYEDI, P.: Wound infection after mandibular reconstruction with autogenous graft. Ann. Acad. Med. Singapore 1986: 15: 340-345.

8. Gersel-Pedersen, N.: Inhibitors of fibrinolysis in saliva after oral surgery measured by enzymic and immunological methods. Int. $J$. Oral Surg. 1979: 8: 212-221.

9. Gersel Pedersen, N.: Tranexamic acid in alveolar sockets in the prevention of alveolitis sicca dolorosa. Int. J. Oral Surg. 1979; 8: 421-429.

10. Hoogkamp-Korstanje, J. J. A.: De normale Flora. In: Mouton R. P., Winkler K. C. \& KOSTER J. F. (ed.): Medische Microbiologie. Bohn, Scheltema, Holkema, Utrecht 1980, p. 166.

11. JAUw, S. L.: The use of homologous lyophilized bone grafts in Hofer's osteotomy. $J$. Max. -fac. Surg. 1983: 11: 113-115.

12. Kloosterman, J.: Köle's osteotomy, a followup study. J. Max.-Fac. Surg. 1985: 13: 59-63. 
13. KREUtzer, H. H. \& RaYmakers, J. A.: Interpretatie van uitkomsten van laboratoriumonderzoek in de geneeskunde. Bohn Scheltema en Holkema, Utrecht 1982, p. 54.

14. KRIZEK T. J. \& ARIYAN S.: Infection. In: CONLEY, J. J. (ed.): Complications of head and. neck surgery. Georg Thieme, Stuttgart 1979, p. 120 .

15. MegQuier, R. J.: Fibrinolytic activity in human dental sockets after extractions. J. Oral Surg. 1971: 29: 321-328.

16. Obwegeser, H. L., Häussler F. \& Ibarra E.: Behandlung des infizierten Knochentransplantates bei der Unterkieferrekonstruktion. In: Pfeifer, G., Schwenzer, N. (eds.): Fortschr. Kiefer-Gesichtschirugie 1984: 29: 76-77. Stuttgart: Thieme.

17. Sandusky, W. R.: Use of prophylactic antibiotics in surgical patients. Surg. Clin. N. Am. 1980: 60: 83-92.

18. SмIтH, H.: Surgical technique. In: Crenshaw A. H. (ed.): Campbell's operative orthopaedics. Mosby, St Louis 1971, p. 54.
19. Stoll P. \& Schilli, W.: Long-term follow-up of donor and recipient sites after autologous bone grafts for reconstruction of the facial skeletal. J. Oral Surg. 1981: 39: 676-677.

20. WEGENER, A.: Eine klinische und röntgencephalometrische Nachuntersuchung der Ergebnisse der chirurgischen Kinnvorverschiebeplastik nach Obwegeser. Thesis, Zürich. Juris-Verlag, Zürich 1971, p. 73.

21. WinKLeR, K. C.: Algemene Besmettingsleer. In: Mouton, R. P., Winkler, K. C. \& Coster, J. F. (eds.): Medische Microbiologie. Bohn, Scheltema, Holkema, Utrecht 1980 p. 67.

Address:

R. Koole

Department of Oral Surgery

Academisch Ziekenhuis Utrecht

Catharijnesingel 101

3511 GV Utrecht

Holland 